\title{
Coming Home: The Bruderhof Returns to Germany
}

\author{
Berit Jany $^{1}$ \\ Department of Germanic Languages and Literatures \\ The Ohio State University
}

\begin{abstract}
The Bruderhof Community, founded by Eberhard Arnold in Germany shortly after World War I, envisions communal life according to the principles of early Anabaptism, Christian Socialism, and the German Youth Movement. Persecuted by the National Socialists in the 1930s, the group migrated to America. Despite harassment and expulsion from Germany, it has attempted to reunite with its geographic birthplace. Reasons for continued efforts to reconnect to the German homeland can be found in the movement's historical development as a free church with a global awareness and outreach. Analyzing the Bruderhof's experience with persecution, its distinct theology, and perseverance as a communal order, I explore the motivations that led to the community's resettlement in Germany and the consequences of that endeavor.
\end{abstract}

\section{Keywords}

Bruderhof, communalism, Eberhard Arnold, Germany, resettlement 


\section{Introduction}

Around 10:00 in the morning of April 14, 1937, about fifty SS and Gestapo surrounded the community of the Rhön Bruderhof, some emerging from the woods, others arriving by car or bicycle. Armed guards positioned themselves at the doors of every building. The forty members of the community were herded into the dining hall, and the Gestapo commissar read out the announcement: The Bruderhof no longer existed. ... Books and papers were carried from the office to the cars below. Three members of the executive committee were questioned at length and then taken away in a Gestapo car (Barth 2010, $1-2)$.

Emmy Barth, one of Eberhard Arnold's descendants and the community's archivist, vividly describes in her book An Embassy Besieged the raid on the Rhön settlement, the siege, the searches and confiscations, and the exile from the German homeland. Although the presence of two Hutterite visitors from North America prevented the Bruderhof's deportation to concentration camps in April 1937, the group suffered severely from the loss of their home and the oppression by the fascist government. Yet, despite the traumatic experience of persecution and expulsion during the Third Reich, the movement maintained close connections to its geographic birthplace and made several attempts to re-establish itself in Germany after years of migration within Europe and America.

Emmy Barth's description of the Bruderhof's steadfastness and its commitment to pacifism while facing harassment by Nazi officials reads like an Anabaptist martyr story set in twentieth-century Germany: "They had pledged their lives—not to Eberhard Arnold but to the kingdom of God - and they trusted that they were in God's hand, even if this meant their deaths" (2). ${ }^{2}$ The community's struggle with oppressive measures by the Hitler regime is reminiscent of the Anabaptists' experience in sixteenth-century Europe, in particular, their conflict with the state over the issue of rejecting worldly authority and military force. Arnold emphasized the Bruderhof's separation from the state, communal order, and pacifist stance in a letter to Reich Bishop Ludwig Müller in 1933. Perceiving his group of followers as a succession of the early Hutterian movement, especially after he received formal confirmation by the Hutterite community during his visit to American colonies in 1930 to 1931, he points out that

Never, in four hundred years, have the brothers named after Jakob Hutter taken part in the power struggles of state politics, political parties, parliamentarianism, and class distinctions, just as they have never had personal property and have never used weapons (Baum 2011, 176).

The Bruderhof shares key principles such as non-violence and communalism with the Hutterite Brethren, and, on two occasions, the two groups joined together as a single Christian communal body (Janzen 2005). However, the two communities were not unified in their effort to revivify the movement in its land of origin. Although the Schmiedeleut Hutterites provided some 
financial support for the Bruderhof's purchase of a building near Bonn during the time of the groups' second merge from 1974 to 1995, they have since withdrawn from mission and settlement initiatives in Germany. The Bruderhof, on the other hand, has been involved in intensive activity devoted to relations with its European homeland. In the past twenty years, Arnold's community has re-established itself in Germany. It has set up two German communal sites and fosters a wide network of relations with other Christian communes, educational centers, and social aid organizations in Germany.

As a twentieth-century Christian commune that has attracted members from different parts of the world during its time of intra- and intercontinental migration, the Bruderhof is characterized by an interest in international involvement ${ }^{3}$ that contrasts with the Hutterites' call for isolation from the outside world. Arnold's group is committed to outreach and service projects in Germany and other countries. In addition to its global mission, economic and sociological factors have contributed to the group's interest in renewing ties with its German homeland. This article reviews the history of the Bruderhof's relationship to its country of origin, reflects on the problems of earlier attempts to resettle the area, and discusses the group's current initiatives in Germany as means of securing the longevity of the communitarian movement.

\section{German Roots}

House Sannerz, the main dining hall, is the central feature of today's large Bruderhof settlements in the United States and England. Named in memory of the first communal site that the movement occupied in Germany, the building represents the heart of each colony. ${ }^{4}$ Murals decorating the walls of these dining halls document the three pillars of inspiration that are essential to the religious and social life of the community. In these colorful paintings, Johann Christoph Blumhardt, young people from the Wandervogelbewegung, and prominent figures of sixteenth-century Anabaptism appear as the spiritual and intellectual roots upon which the Bruderhof movement has developed. When visiting any of the Höfe in the United States or abroad, members of the community enjoy sharing information about the religious and social movements that inspired Arnold to establish this unique Christian commune.

Eberhard Arnold turned to the concept of Christian Socialism when he sought answers to the devastation and social injustice encountered in the aftermath of World War I. In his last letter to the community in 1935, he mentioned the two Blumhardts and their attitude of faith (Baum 2005). Johann Christoph Blumhardt (1805-1880) and his son Christoph Friedrich (1842-1919) worked as pastors in Baden-Württemberg until Friedrich was forced out of the state church due to his affiliation with the Marxist party. With his idea of social democracy being a representation of the instrument of the living God, Friedrich became an inspiration for Swiss Religious Socialists like Leonhard Ragaz and Hermann Kutter (who introduced Arnold to Blumhardt's theology) and twentieth-century Protestant theologians, most prominently Karl Barth (Buess and Mattmüller 1989). Blumhardt combined the notion of the coming of the kingdom of God with the belief in socialist progress (Buchholz 2010). Arnold highly valued this combination of 
spiritual-mindedness and social concern, and derived a practical Christianity from Blumhardt's philosophy that envisioned a radical discipleship to Christ, including a rejection of violence and materialism (Arnold and Arnold 1974).

A communal spirit was also communicated through the Wandervogelbewegung that arose formally in a suburb of Berlin in 1901 and presented a juvenile reaction against the values and lifestyle of the urban middle classes (Williams 2007). As part of a wave of neo-Romanticism that swept Germany in the early twentieth century, the youth movement developed an anti-capitalist world view and voiced criticism about the moral and social implications of modern civilization and its drive for progress (Löwy 1993). Members of the youth movement expressed their opposition to the restrictive urban society through a return to nature, abstinence from alcohol and tobacco, communal living, modest dress, and the call for freedom and self-responsibility. They formed small groups (some of them mixed gender) allowing for genuine friendship and coherence between members. These groups were involved in expeditions, singing, camping, amateur theatrical performances, and hiking, and gathered at local and national youth conferences. Eberhard Arnold came in contact with the Wandervogelbewegung in 1917 when attending one of its conferences. According to Tyldesley (2003), members of the movement were involved in discussion groups at Arnold's home in Berlin that preceded the formation of the Bruderhof. As active participants of the Free German Youth, Arnold and his wife appreciated the movement's social and economic reforms and rediscovery of folk traditions. They incorporated some of the Wandervogelbewegung virtues into the Bruderhof, and even today spontaneity, closeness to nature, and simplicity are greatly valued by the community (Whitworth 1975). ${ }^{5}$

The third fundamental aspect of the Bruderhof mentioned in Arnold's last testament is early Anabaptism, in particular, the Christian radicalism of the sixteenth-century Hutterites. The Hutterian faith and form of living inspired the Arnold circle to establish a Bruderhof near Fulda, modeled after the example of the Anabaptist communal household. On his search for radical discipleship, Arnold learned about the history of the peaceful Anabaptists. He read about their persecution and martyrdom in the sixteenth century and serendipitously discovered their continued existence in North America. After his visit to all 33 Hutterite colonies in the United States and Canada in 1930 to 1931, he was appointed servant of the Word by the Hutterite elders. Witnessing the brethren's sharing of goods, work, and life, their refusal to do military service, and their commitment to the church as the body of Christ, he felt encouraged to establish an intentional community that is based on the Hutterite communal order. In his testamentary letter, he suggests that he drafted the Bruderhof communal order (Gemeindeordnung) after the Hutterianism of the sixteenth century rather than the seventeenth-century Hutterite faith practices favored by the American colonies, an aspect that later led to conflict in the relationship between the Bruderhof and contemporary Hutterians (Janzen 2005).

As vivid descriptions and artwork of the group's early commune life in Hessen indicate, the Bruderhöfer are fascinated with their movement's German history. They trace their theological, social, and spiritual roots to the German nation and carefully preserve this genealogy 
of ideas in books and periodicals printed by Plough, a publishing house operated by the community. The group's early stages of development in Germany were such a profound experience that not even the persecution and expulsion during the country's National Socialist period caused permanent damage to the relationship of the Bruderhof to its land of origin.

To be sure, the imprisonment of members, confiscation of property, and exile from the homeland left marks on the group’s shared memory of Germany. Arnold's followers encountered major difficulties and pressures from the Hitler government when avoiding covert resistance on the one hand and complicity on the other. Although they attempted to stay true to the nonviolent principle and sent petitions to state officials stressing the brotherhood's pacifist stance, they quickly realized that their faithful community is to Nazi Germany "less than a gnat to an elephant” (Baum 2005). Yet, the group’s struggle with National Socialism followed by the ordeal of seeking refuge in Europe and living in Paraguay's chaco, significantly contributed to its collective identity. The brotherhood still frequently refers to their suffering at the hands of the Nazis as an example of the wickedness of the world in order to justify their separation from the dominant society.

While the years of persecution and intercontinental migration were filled with troubles and suffering, the Bruderhof managed to flee Europe's war scene without any casualties. ${ }^{6}$ Unlike their Hutterite predecessors who suffered inexorable oppression, torture, and execution through sixteenth-and seventeenth-century authorities, the Bruderhöfer did not lose a single life at the hands of the Nazis. When reading accounts of the group's historical witnesses and speaking to their descendants and other community members, it appears that the memory of the brotherhood's brave attempt to confront the Third Reich with Christ's peaceful teachings outweighs the experience of persecution. The focus on the community's courageous testimony to peace rather than the perpetration of violence through the fascist state undoubtedly contributed to the Bruderhof's interest of bringing the community back to German soil after the end of World War II.

\section{Post-War Settlements in Germany}

The first attempts to renew relations between the Bruderhof and its German homeland were made in the early 1950s. Especially Hans Zumpe, Eberhard Arnold's son-in-law, devoted his efforts to reaching out to religious and pacifist circles in Germany and renewing the group's relation to its geographic birthplace. As a "true German," he gave his heart to the dream of reestablishing a colony in Germany (Zablocki 1971). ${ }^{7}$ In his 1956 article in The Plough, the Bruderhof's quarterly publication, Zumpe explains the reasons for the importance of reviving the community's ties with Germany. In his opinion, the country's conditions were ripe for the group to "fill a role in the spiritual enthusiasm that had gripped the young people of that country" (cited in Oved 1996, 170). The Bruderhof considered the institutionalization of civilian service (Zivildienst), offered as an alternative for the compulsory military service, as an opportunity to perform service of peace in German community life. 
In order to support conscientious objectors in Germany and disseminate pacifist literature, the group acquired property in 1955 at the historical site of Hohenstein Castle, in the mountains of Franconia near Nürnberg. For about six months, the Bruderhof building was home of 25 members who welcomed a total of 100 visitors and established a relationship with Nürnberg's pacifist group, "The Brothers of Common Life.” The time in Hohenstein also gave the brethren the opportunity to hold a conference for graduates of the German youth movement and reconnect with people that had been close to the brotherhood in the past (Oved 1996).

Later that year, the community purchased an estate called Sinntalhof, near the spa of Bad Brückenau in Lower Franconia. The Sinntalhof covered about twenty acres and consisted of a number of buildings that were part of a boarding school prior to the Nazi rise to power. According to Bruderhof veterans who visited the Sinntalhof in the 1950s, the community site was within walking distance from the 1930s Rhönhof. In addition to the 25 members who inhabited the Hof and renovated the buildings, several of the Bruderhöfer from England and the United States came to visit Sinntalhof to reconnect with their German heritage. In 1958, after the American colony started Community Playthings-a wood-working business that manufactures children furniture and toys - the German community set up a factory for the production of boxes and toys in cooperation with the U.S. factory.

In their efforts to re-establish relations with Germany, the Bruderhof community became involved in a number of service and mission projects. The brethren visited refugee camps, sent emissaries to various religious and pacifist circles, and presented themselves at church conferences such as the 1956 German Quaker Conference and the Conference of Protestant Churches (Oved 1996). Their presence in Germany, however, did not last long. When a groupinternal crisis arose among the Bruderhöfe during the late 1950s, the leadership in the Woodcrest colony in New York decided to focus on solving inner problems rather than supporting outreach. ${ }^{8}$ According to Zablocki (1971), the Bruderhof came to realize that it had over-extended itself and began to cut its losses through consolidation. As part of its measures against the great crisis, the Sinntalhof was disbanded in 1961.

It was not until the 1980s when the Bruderhof decided to once again revivify community life in its European homeland. At that time, the movement was devoted to relations with the outside world as a means to stimulating internal developments. The Bruderhöfer came to realize that encounters with the outside did not only bring new members to the group but also generated a high retention rate among their own young people. As Oved has pointed out, many of the second-generation people decided to join the community after having spent a number of years experiencing life outside the commune (1996, 278). As part of its initiative to strengthen communal life and be involved in outreach, the Bruderhof merged with a group of Schmiedeleut in 1974 and started joint mission projects in Germany and Palmgrove, Nigeria.

The community started the mission of re-establishing itself in Germany by purchasing a building located near the city of Bonn. In 1988, the first Bruderhof families moved to Haus 
Waldfrieden, which was financed by both the Hutterites and Bruderhöfer. Within a short period of time, new people from Europe and other Bruderhof families joined the small commune so that a larger property could be acquired in the nearby village of Birnbach in the same year. The new community site, Michaelshof, consisted of about 60 acres of land and a number of buildings. Both groups were involved in setting up the German colony, the Hutterites financially and the Bruderhof with personnel. In 1989, the population of the new Hof numbered about 80 people, and many visitors from the United States and Europe came to experience community life. During their time at Michaelshof, the Bruderhöfer intensified their relationship between themselves and the Basisgemeinden, Christian communities in Germany, which also maintain a communal way of life. The Bruderhof had already established economic relations with the Basisgemeinden in 1983 when it entrusted them with the distribution of their Community Playthings products in Germany.

The Bruderhof experienced difficulties when setting up their second community in Birnbach. Although a great awakening swept parts of the world since the 1960s (including Germany), provoking the establishment of ecclesial communes such as the Basisgemeinden, villagers in Rhineland-Palatine viewed the Bruderhof settlement with much suspicion. According to Janzen (2005), who visited Michaelshof in 1994, the community encountered xenophobia among Birnbach's inhabitants. The locals_-some of whom closely identified with a far-right German nationalistic party — did not like the fact that a group of English-speaking foreigners with different beliefs and practices had taken up residence in their neighborhood. These intolerant villagers prevented the granting of permits for the construction of new buildings at the Michaelshof, in particular the communal dining hall and the factory, both essential elements of the Bruderhof's community life.

When the movement finally decided to close down the German commune and move its members to England in 1995, the Servant of the Word Jorg Barth said in an interview with the local newspaper (Rheinische Zeitung) that some of the villagers did everything in their power to frustrate the community and hinder its members from starting a real Bruderhof in Birnbach (cited in Oved 1996, 317). Disappointed by the discrimination experienced during the settlement efforts in the 1990s, the community did not re-establish itself in Germany until 2002.

\section{Current Initiatives in Germany}

Notwithstanding the disbandment of the Hof in Birnbach, the movement continued relations with religious and communal circles in Germany. It maintained strong ties to the Basisgemeinden (for instance, the Brüdergemeinde Korntal near Stuttgart). Furthermore, the Bruderhöfer in the United States and England continued to commemorate their German roots and made efforts to preserve this European heritage by integrating German customs, songs, and language ${ }^{9}$ into their daily communal life. The community also passed on its German history through the publication of Arnold's foundational writings. Shalom groups, consisting of young, unmarried Bruderhof members, frequently read and discussed the works of Blumhardt, Arnold, 
and Barth. ${ }^{10}$ Moreover, on American and English Höfe, community schools started a class that provides students with a comprehensive introduction to the movement's history and orients them in the concepts underlying Arnold's social and theological initiatives. School classes in England have also taken the opportunity and visited important sites of the community's early development during a field trip to Germany and Switzerland. ${ }^{11}$

On one of these excursions to Germany in 2002, a group of Bruderhof students from England discovered that the building in Sannerz, which served as the community's first home, was for sale. With financial support from the international community, the group purchased the property and re-established a commune on the original Bruderhof ground. The same year, Sannerz became the home of two Bruderhof couples and a few single members who started outreach in the area. After the hostility experienced by neighbors in Birnbach, the Bruderhöfer were determined to cultivate contact with the local community in Germany. The group became actively involved in the village life of Sannerz and opened its doors to visitors from Germany and other parts of Europe.

After the successful settlement of the Bruderhof in Sannerz, the community decided to establish Holzland, a second German communal order in the village of Bad Klosterlausnitz. According to group members, the community sought to settle in this part of former East Germany because of its geographic proximity to Halle, a university town where Arnold began his study of theology in 1906. Located in central Thüringen, Holzland is not far from Keilhau, a town that is linked to the Bruderhof history through Annemarie Wächter, who grew up in this area and later became a close friend of Arnold's daughter Emy-Margret, and who, in 1932, joined the Bruderhof. ${ }^{12}$ Annemarie’s father, Otto Wächter, served as the principal of the Fröbel school that was first founded by the renowned pedagogue Friedrich Fröbel in $1817 .{ }^{13}$ In the past years, the Bruderhof has sent out young sisters to volunteer at the Freie Fröbelschule Keilhau. ${ }^{14}$

Today, each German Hof houses about 20 Bruderhöfer and a number of interested visitors. After a period of testing different employment options-members at Holzland, for instance, worked on construction sites, in private gardens, and as English tutors to earn some income - both German communities established small factories for the production of wooden items in cooperation with Bruderhof factories in England. The group also sends some of the community's high school graduates to work as apprentices in local plumbing, carpentering, and technician businesses and has recently launched a project to train interested members to become certified teachers in Germany. As part of this initiative, young American members study German at the university level and participate in summer study abroad programs to prepare them for the intensive teacher training at German universities. ${ }^{15}$

\section{Community Commitment through German Experience}

Since the 1960s, the Bruderhof has not experienced a great influx of members from outside the Bruderhof's own ranks. Most Bruderhof candidates are born in the communitarian 
group and enter the novitiate directly from their membership in a Bruderhof family (Zablocki 1971). While the community is currently raising its fifth generation of sabras, ${ }^{16}$ it faces issues of spiritual regression. A full commitment to the communal life can only be generated by a freedom of choice (Brumann 1998). Yet, this freedom is curtailed in the Bruderhof through socialization processes that have the consequence of limiting the range of alternatives from which the sabras are expected to choose (Goldenberg and Wekerle 1972). In the past decades, the Bruderhof youth were sent to public high schools in preparation for the decision between life in the outside world and life in the community. In 2011, however, frustrated by the schools' excessive use of technology and permissive sexual attitudes among peers, the American Höfe established the “Academy," a community-run boarding school where all Bruderhof children complete their high school education.

The Bruderhof's highly sophisticated educational system supports a peculiar socialization that prevents sabras from making a "legitimate" continuance commitment to their communities (Goldenberg and Wekerle 1972). As they lack an understanding of the outside world, it is difficult for them to feel called to a life into which they instinctively feel that they have been born. Yet, the group does not tolerate the presence of uncommitted individuals in its midst. It therefore attempts to secure the young people's commitment through other forms of exposure to the outside world. Germany, in particular, offers a place in which young people are able to gain experience outside the community while maintaining close ties with the Bruderhof.

Young folks from the English Bruderhöfe, in particular, are sent to Germany after completing their twelve years of formal education. Employment authorizations for all members of the European Union allow Höfe in southeast England to place their youth in German apprenticeship programs and vocational trainings. In the past years, graduates of the Darvell Bruderhof have come to Holzland to begin apprenticeships in skilled trades. Young female graduates frequently work as aides in private schools and child care centers (such as the Freie Fröbelschule Keilhau and a family center in Berlin), and provide assistance for various Basisgemeinden. While many of these young people live outside the Hof during their trainings and assistantships, they spend their weekends with fellow Bruderhöfer on one of the German communal sites. Although their experience in the movement's European homeland is largely controlled by the group, thus inhibiting truly free choice, the young people receive more confidence in their commitment to the community after temporary exposure to some of the life outside the commune and the completion of vocational trainings.

\section{Isolation and Outreach on German Bruderhöfe}

As a communitarian movement with a long duration, the Bruderhof is concerned with the balance between isolation from and involvement with the outside world. Since its beginnings, it has demonstrated a dual commitment to withdrawal from the world and to evangelism (Tyldesley 2003). On the one hand, community members have signaled an interest in world-transforming activities and outreach, for instance, by participating in peace rallies, working in urban renewal 
projects, and attending social and religious conferences. On the other hand, they have made an effort to separate from the larger society as a means of maintaining internal purity (Whitworth 1975). The Bruderhof condemns today's world as a place of selfishness, violence, and sexual corruption, and therefore shuns the contamination of worldly interests and associates.

This commitment to both separation and outreach derives from the movement's founding influences. From the Wandervogelbewegung with its rejection of traditional social structures and its withdrawal from urban, middle-class society, the Bruderhof has adopted a separatist notion, by which it avoids assimilation into the materialistic culture of modern society. In the spirit of the German youth movement as well as Christian Socialism, the brotherhood attempts to establish an alternative social order that is free of violence, power hierarchy, and capitalistic influence. At the same time, the Bruderhof follows the example of early Anabaptism when seeking contact with the outside world for the purpose of evangelization. While other Anabaptist groups, such as the Amish and Hutterites, lost the early movement's sense of mission in the seventeenth and eighteenth centuries, the Bruderhof has developed an emissary system that is reminiscent of planned outreach programs by original Anabaptists to gain new members.

As a result of the Bruderhof's diverse influences, the ideological commitment both to internal purification and to active response to developments in the external society manifests itself in communal management, practices, and initiatives that are visible on German community sites. Following the call to withdrawal from corruption and violence of the outside world, the two German Bruderhof communes have adopted ways of separating members from the host society. The communities resist the forces of assimilation in the larger German society through geographic isolation. Both Höfe are situated in remote areas of central Germany. Holzland, for instance, is located on the periphery of the small village of Bad Klosterlausnitz. The location of the communal order in the Thüringen countryside enables the group to explore the natural environment and to incorporate it into their lives, much in the tradition of the Wandervogelbewegung. In addition to the small size of the Hof that allows for a close monitoring of group members, the geographic isolation helps the community to control the exposure of their young people to the outside world.

The German Bruderhöfe also maintain boundaries to the host society by establishing a self-sustaining community. They train their novitiates in professions essential to communal life, set up their own factories, and assign native speakers to the Höfe to help with matters of German bureaucracy. As part of their commitment to withdrawal from the outside world, the group endeavors to develop its own private schools in Germany. In the past years, families had to leave the German communities once their children turned six. The German educational system makes a distinction between compulsory schooling (Schulpflicht) and compulsory education (Bildungspflicht). Since the law on compulsory schooling prohibits home schooling, the community is obliged to send its children to public schools. It has therefore started preparing some of its youth to study at German universities to attain teacher licensures so that private Bruderhof schools will be staffed with certified teaching personnel as required by the state. 
While the German Bruderhöfe make an effort to set up their own schools in order to minimize their children's exposure to the outside world, the communities do not shun the idea of involving interested people from the larger society into their educational program. Similar to the "Academy" that has accepted non-Bruderhof students to attend classes, ${ }^{17}$ the German communities plan on opening their schools to children of interested families in the area.

Although committed to a withdrawal from the abominations of the world, the Bruderhof is also considered an involved communitarian order since it feels it has something relevant to say to the people of its host society (Tyldesley 2003). In recent conversations, Bruderhof members shared their observations about changes in German society. Similar to Zumpe's witness to a new age of German spiritual enthusiasm in the 1960s, today's Bruderhöfer believe that a new generation has developed in Germany that seeks spiritual fulfillment. The group claims that young people in particular are frustrated with today's culture, determined by materialism, self-centeredness, and corruption, and therefore seek new forms of social units, such as communal living, with an emphasis on a set of shared moral and social values. The German Höfe invite those who are seeking to visit their communities and generously supply them with publications of their foundational and contemporary writings translated into German.

When the Holzland communal site in Thüringen was established almost ten years ago, the Bruderhöfer first encountered difficulties with the local community. Although East and West Germany had been reunited 15 years prior to the group's settlement in Bad Klosterlausnitz, the mentality of suspicion continued to thrive in provincial towns and villages in the former East. The commune's foreign tongue (most of the Bruderhof members spoke English), strange clothing habits, and unfamiliar communal practices raised suspicion among the villagers. Moreover, the frequent transfer of community members added to the disconcertment of the people in Bad Klosterlausnitz. It took some time and effort for the community to be accepted by its host society. One way of building rapport with the villagers has been the appointment of native Germans who have joined the movement as adults to spokespersons for the German sites. For the past years, the support by German community members has been substantial for the newly founded settlement. Holzland's native speakers - at least one is present in the community at all times-perform essential delegation and outreach duties that connect the Bruderhof to the local population.

The Bruderhof has established a presence in Bad Klosterlausnitz through a range of outreach activities and community work. Its involvement in service projects helps members to become part of village life while simultaneously promoting Christian faith, family values, and global understanding. When the Bruderhöfer first settled in the area, they offered English tutoring, a service that was appreciated by villagers who had only learned Russian in Cold War times and thus welcomed the opportunity to become familiar with a language widely spoken in the western world. Today, the Bruderhof community maintains good relations with its German neighbors. ${ }^{18}$ Members of Sannerz and Holzland frequently welcome villagers to their Höfe for Saturday dinners and invite local children for nature excursions and play dates with the 
commune's offspring. The German communities also provide help for local retirement and nursing homes as well as spiritual support for struggling individuals.

\section{Conclusion}

Through the tragic events in World War II, the Bruderhof was forced to leave its German homeland and embark on a long journey that eventually led to prospering settlements in the United States. But unlike earlier Anabaptist immigrants in America, Arnold's community maintained close ties to its geographic birthplace. The brotherhood's distinct character, rooted in sixteenth-century European Anabaptism, the Wandervogelbewegung, and Christian Socialism in early twentieth-century Germany, led to mission work and global outreach that included a revival of the movement in its land of origin. Throughout the past 80 years, the community has been involved in keeping its connection with Germany and developing new relations with the contemporary German society.

With its pacifist position, communal practices, and nostalgia for rural life and folk traditions, the Bruderhof felt drawn to post-war Germany. It has attempted to provide an alternative style of life for those Germans seeking to follow Christ and rejecting the materialistic culture of the dominant society. The spirit of change prevailing in the 1960s and 70s, with the concern for non-violence and interest in experimental forms of living together, further encouraged the brethren in their endeavor to re-establish the movement in Germany. Moreover, the recent discourse on post-secularism has inspired the Bruderhöfer to renew ties with the European homeland. They have become aware of notions in contemporary German society by which individuals and groups set themselves against the overvaluation of material things, and, instead, develop a religious sensitivity of outlook on the world.

The efforts to revive the Bruderhof movement in Germany have taken different forms. The community sought to reconnect with its European homeland by supporting religious and pacifist circles, investing in service and mission work, and building community sites. However, group-internal crises and xenophobic tendencies among members of the German host society caused failure for the permanent resettlement of the original land during the second half of the twentieth century. It appears that the current German Bruderhof communes, developed within the past decade, are more successful than earlier settlement initiatives and may continue to grow as the movement overcomes institutional and administrative obstacles.

The success of the most recent Bruderhof settlements in the German states of Hessen and Thüringen can be traced back to external as well as internal factors. On the one hand, Germany has developed a greater global awareness and tolerance toward social and religious minority groups. Perhaps dissatisfied with increasing consumerism and the effects of recent economic crises, some Germans seek to re-establish a sense of purpose beyond self, thereby reacting positively to the Bruderhof's communal way of life. On the other hand, the community has made a greater effort to develop a relationship to the German host society. Germany appears to 
accommodate the movement's dual commitment to outreach and withdrawal. While the European state allows the Bruderhof to maintain a separation from the dominant society, it also provides a platform for mission work and community outreach. Vocational training and service work in Germany offer a form of exposure to the outside world that reaffirms sabras' full commitment to the communitarian order.

\section{Endnotes}

${ }^{1}$ Contact information: Berit Jany, Ohio State University, 336 Hagerty Hall, 1775 College Road, Columbus OH 43210; jany.1@osu.edu

${ }^{2}$ In fact, the English publication of the Hutterian history and martyr book, Das KleinGeschichtsbuch der Hutterischen Brüder, translated by Arnold's community, includes an account of the Bruderhof's struggle during the rise of National Socialism in Germany, in particular, the dissolving of the Rhön Hof in 1937.

${ }^{3}$ The recent change of name to Church Community International refers to the movement's global engagement and its establishment of colonies on three continents. Due to the article's focus on the brotherhood's relationship to Germany, the author employs the German term Bruderhof that is still used informally by members of the community in the United States and in Germany.

${ }^{4}$ A picture of a blazing sunheart (perhaps a reference to the proposed name change of Sannerz to "Sonnherz"-“Sunheart” in the 1920s), designed by Karl Mahr, an artist friend of the Arnold family, is found on each of the settlements' main dining halls. The heart radiated by sunlight is emblematic for the movement's mission of love, peace, and nonviolence.

${ }^{5}$ Many of the Free German Youth practices are still alive on Höfe, for instance simple and colorful clothing, nature hikes, and campfire songs. Although the Hitler Youth took certain forms from the Wandervogelbewegung, for instance its songs, thereby banning them from usage in contemporary Germany, the Bruderhof communities continue to sing these Lieder as they retain their original meaning for the exiled brotherhood.

${ }^{6}$ However, the group did suffer severely during their time in the Paraguayan exile. Tropical diseases and unfamiliar climate caused the death of several mothers and children.

${ }^{7}$ Together with Arnold's three sons, Peter, David, and Johann Paul, Hans took a leadership role in the community. In the 1950s, Peter and David began expanding the brotherhood in the U.S. while Johann Paul supported the colonies in South America, and Hans sought to revive the community in Germany.

${ }^{8}$ The power struggle between Arnold's sons and Hans Zumpe came to an end when it was revealed that Zumpe committed adultery with his secretary at Sinntal. When he was expelled from the group, the movement lacked a central figure of the European outreach initiative. 
${ }^{9}$ After the Hutterite-Bruderhof division in 1995, some members of the Schmiedeleut colony decided to join the so-called “Arnoldsleut," bringing some of the Hutterite's Upper German dialect into the community. Yet, most of the German terms in the Bruderhof's vernacular are remnants of its pioneer time in 1920s Germany. German terms such as Lieder (songs) and Reigen (round dance) are reminiscent of the movement's closeness to the Wandervogelbewegung and are even used in form of loan words by non-German speaking members. Terminology referring to theological aspects, such as Gelassenheit (a 'letting-go' of temporal things in the awareness that God's will) entered the Bruderhof's vernacular through Arnold's study of early Anabaptism.

${ }^{10}$ The community's publishing house has recently reprinted the translation of Arnold's major works, for instance Salt and Light (2012) and The Individual and the World Need (2011).

${ }^{11}$ Students at the Darvell Bruderhof in the south of England put together a two part movie “The Embassy" in 2010 in which they reenacted Arnold's struggle with the Nazi regime. The class visited Germany and Switzerland to film at the actual locations of the Bruderhof's history.

12 Annemarie's experience as a kindergarten teacher during the Bruderhof's time in Europe and its migration to Paraguay has been captured in the book Anni (2011) published by the community run printing house.

${ }^{13}$ Members of the Bruderhof explained in conversations with the author that Fröbel's ideas about childhood development and education, in particular, his recognition of games' educational worth and his emphasis on activities and play in early childhood education, have significantly determined their group's educational methods and directions.

${ }^{14}$ The position of the principal at the Fröbel school has been passed along the Wächter family for generations. After Annemarie's father retired in 1934, her brother Reinhold took office as principal. Until the summer of 2011, Gabriele Wächter, another member of the Wächter pedagogical dynasty, served as principal of the Freie Fröbelschule Keilhau.

${ }^{15}$ A few Bruderhof novitiates currently study German at the West Virginia University and have participated in the university’s study abroad program in Fulda, near the Sannerz Hof.

${ }^{16}$ The Hebrew term sabra (often used for Jews born in Israeli kibbutzim) refers to members who were born in one of the Bruderhof communities.

${ }^{17}$ In the 2012-13 school year, two students from outside the community were enrolled in the Bruderhof's boarding school at the Mount Community in Esopus, NY.

${ }^{18}$ Before visiting the Holzland community in 2011, the author spoke with locals about the Bruderhof's presence in Bad Klosterlausnitz. The interviewees gave favorable accounts of the community, expressing their appreciation for the brotherhood's involvement in charitable 
activities and community outreach. While taking a walk through the village neighborhood with a few Bruderhöfer, the author noticed the group's integration into the village community. The sisters were greeted warmly by their neighbors and engaged in conversations with some of the locals.

\section{Appendix: Glossary of German Terms and Commune Sites}

\section{German Terms}

The Basisgemeinde (Basic Ecclesial Communities) is a Christian movement that was inspired by the Liberation Theology in Latin America in the 1960s. It seeks a concrete realization of the communitarian model proposed by the Second Vatican Council. The Basisgemeinden consists of small clusters of parishioners, each under the direction of lay or religious leaders.

Bruderhof: The term Bruderhof (place of brothers, the house and farm of monasteries), was used to describe early Hutterite settlements in East Europe. In the context of Eberhard Arnold's religious community, the term refers to the movement as such and to its communal sites.

Bruderhöfer are members of Bruderhof communities, both in Europe and America. After Eberhard Arnold was confirmed by the Hutterites in the 1920s, his followers were also called Arnoldleut.

Höfe: As a shortening of the term Bruderhöfe, Höfe refers to the movement's communal sites in Europe and America.

Wandervogelbewegung is a popular movement of German youth groups from 1896 onward. Wandervogel (wandering bird) symbolizes the movement's ethos of escaping the restrictions of society by returning to nature and seeking freedom and self-responsibility.

\section{German Commune Sites}

Haus Sannerz: Located in the village of Sinntal-Sannerz, about an hour northeast of Frankfurt, Haus Sannerz was the first communal building of the Bruderhof movement. The building, an old brick mansion not far from Fulda and Frankfurt, was built in 1906 by Konrad Klee, a re-migrant from America. Eberhard Arnold rented the mansion as a living space for his newly founded religious community in 1920. In the following six years, Arnold's group outgrew the house and had to move to a property in the nearby Rhön Mountains. In 2002, the Bruderhof purchased the original Sannerz building and started a small community there.

Haus Waldfrieden: Financed by Hutterites and Bruderhöfer in 1988, Haus Waldfrieden, located near Bonn, became the movement's new outpost in Germany. Due to the rapid growth of the community in Waldfrieden, the Bruderhof had to relocate to a larger property in the same year. 
Michaelshof: In the years 1988-1995, the Michaelshof served as the German communal site for Bruderhöfer and affiliated Hutterites. The settlement was located in the village of Birnbach, in the state of Rhineland-Palatinate, where a number of xenophobic and rightist inhabitants caused difficulty for the brotherhood to establish a permanent home in the area.

The Rhönhof, a farm near Fulda, set in the Rhön Mountains, became the movement's second settlement in Germany. Arnold bought the property, also known as the Sparhof farm, with a generous donation from Prince Waldenburg Schönburg in 1926. Members of the brotherhood remained on the Rhönhof until the year 1937 when the Nazi regime started persecuting the group.

Sinntalhof: After World War II, the community bought property in Lower Franconia, near its pre-war settlement in the Rhön Mountains. The Sinntalhof served as the Bruderhof's German communal site from 1955-61.

\section{References}

Arnold, Eberhard, and Emmy Arnold. 1974. Seeking for the Kingdom of God. Origins of the Bruderhof Communities. Rifton, NY: Plough Publishing.

Barth. Emmy. 2010. An Embassy Besieged. Rifton, NY: Plough Publishing.

Baum, Markus. 1998. Against the Wind: Eberhard Arnold and the Bruderhof. Rifton, NY: Plough Publishing.

Brumann, Christoph. 1998. Die Kunst des Teilens. Eine vergleichende Untersuchung zu den Überlebensbedingungen kommunitärer Gruppen. Hamburg: Lit Verlag.

Buchholz, Christian. 2010. Christoph Friedrich Blumhardt - Reich Gottes in der Welt. Göppingen: Manuela Kinzel Verlag.

Buess, Eduard, and Markus Mattmüller. 1986. Prophetischer Sozialismus. Blumhardt Ragaz Barth. Freiburg/Schweiz: Ed. Exodus.

Goldberg, Shelton, and Gerda R. Wekerle. 1972. "From Utopia to Total Institution in a Single Generation: The Kibbutz and the Bruderhof.” International Review of Modern Sociology 2:224-32.

Janzen, Rod. 2005. “The Hutterites and the Bruderhof: The Relationship between an Old Order Religious Society and a Twentieth-Century Communal Group.” Mennonite Quarterly Review 79(4):505-44.

Löwy, Michael. 1993. On Changing the World. Atlantic Highlands, NJ: Humanities Press. 
Oved, Yaacov. 1996. The Witness of the Brothers: A History of the Bruderhof. Piscataway, NJ: Transaction Publishers.

Tyldesley, Michael. 2003. No Heavenly Delusion? A Comparative Study of Three Communal Movements. Liverpool: Liverpool University Press.

Whitworth, John McKelvie. 1975. God's Blueprints. A Sociological Study of Three Utopian Sects. London: Routledge \& Kegan Paul Ltd.

Williams, John A. 2007. Turning to Nature in Germany: Hiking, Nudism, and Conservation, 1900-1940. Palo Alto, CA: Stanford University Press.

Zablocki, Benjamin D. 1971. The Joyful Community: An Account of the Bruderhof: A Communal Movement Now in Its Third Generation. Chicago: University of Chicago Press. 